\title{
PERBANDINGAN KEMAMPUAN MEMBACA PERMULAAN ANTARA METODE SUKU KATA DENGAN METODE EJA BERBANTUAN MEDIA KARTU KATA
}

\author{
Rismawati $^{1}$, Kadek Dewi Wahyuni Andari ${ }^{2}$, Kartini $^{3}$ \\ Universitas Borneo Tarakan \\ Jalan Amal Lama Nomor 1 Tarakan Kalimantan Utara \\ rismawatipgsd15@gmail.com
}

\begin{abstract}
This study aims to determine differences in student's initial reading skills by Applying the Syllable Method aided and Spell Method by Word Card Media for Class II at SDN 024 Tarakan. The type of this research is quasiexperimental research. This research was conducted in August 2019. With a population of class II of SDN 024 Tarakan and the sample consisted of two classes, namely class II D as an experimental class and class II C as a control class. The technique in taking the sample used is Random Sampling. The research data were processed with the help of SPSS V.21 for Windows Software. The results showed that there were no differences in the results of the ability to read the beginning by applying the Syllabic Method and Spell Method Assisted Media Media Card Word. The results of the Independent Sample T-test on student's initial reading ability were obtained tcount $=0.045$ at the significance level of 0.05 and $d f=53$, obtained table $=2.01$ means $t_{\text {count }} \leq t_{\text {table }}$.
\end{abstract}

Keywords: Syllable Method, Spell Method, of Word Card Media Assistance, Beginning Reading Ability.

\section{Pendahuluan}

Tingkat perkembangkan teknologi pada saat sekarang mengharuskan manusia untuk maju dalam berbagai ilmu pengetahuan. Hal tersebut menjadi salah satu motivasi Negara untukmemajukan kesejahteraan bangsanya. Salah satu yang dilakukan oleh Negara adalah melalui pendidikan yang baik dan terarah. Melalui pendidikan seseorang dapat mengembangkan bakat dan potensi yang dimilikinya. Menurut Undang-undang Nomor 20 tahun 2003 tentang pengertian pendidikan adalah sebuah usaha yang di lakukan secara sadar dan terencana untuk mewujudkan suasana belajar dan proses pembelajaran agar peserta didik secara aktif mengembangkan potensi dirinya untuk memiliki kekuatan spiritual keagamaaan, membangun kepribadian, pengendalian diri, kecerdasan, akhlak mulia, serta keterampilan yang diperlukan dirinya, masyarakat, bangsa, danNegara.

Pendidikan sangat penting untuk menunjang kemajuan suatu masyarakat, maka pendidikan harus ditanamkan sejak dini. Langkah awal yang dapat dilakukan adalah dengan memberikan pendidikan literasi pada siswa sejak awal masuk sekolah ataudi bangku sekolah dasar. Menurut Surangga (2017:159) Literasi adalah kemampuan untuk mendengarkan, berbicara, membaca, menulis, dan menghitung (counting) berkaitan dengan kemampuan analisis untuk memperhitungkan (calculating), mempersepsikan informasi (perceiving), mengkomunikasikan, serta menggambarkan informasi (drawing) berdasarkan pemahaman dan pengambilan kesimpulan pribadi. Namun saat ini kegiatan literasi masih sangat kurang di Indonesia, menurut Yusuf (2010:134) literasi membaca siswa Indonesia dapat digolongkan sangat rendah dibandingkan dengan siswa seusia mereka yang ada di mancanegara terbukti dalam hasil penelitian PISA (Programme For International Students Assessment) peringkat Indonesia berada diperingkat 64 dari total 72 negara, khususnya di daerah Kalimantan Utara yaitu hasil program literasi Kalimantan Utara sumber dari Asesmen Kompetensi Siswa Indonesia (AKSI) Kemendikbud 2016 menunjukkan bahwa sebanyak $60,67 \%$ kemampuan membaca anak kurang, 36,96\% cukup dan hanya 2,36\% anak di Kalimantan Utaramemiliki kemampuan membaca yang baik. Data tersebut juga menempatkan kemampuan membaca anak Kalimantan Utara pada posisi kedua terendah secaranasional.

Berdasarkan hal tersebut membuktikan bahwa literasi masih rendah dalam penerapan yang dilakukan oleh sekolah-sekolah. Literasi sendiri sangat berkaitan dengan kemampuan berkomunikasi siswa terhadap lingkungannya. Berdasarkan perkembangan teknologi saat ini, 
ketersediaan informasi sebagian besar di sajikan dalam bentuk teks. Maka siswa dituntut untuk memiliki kemampuan membaca yang tinggi.Kegiatan membacaakanmenambah pengetahuan siswa melalui informasi-informasi yang dibacanya, baik dari buku maupun berbagai informasi lainnya yang tersedia dalam bentuk teks.

Membaca sendiri menurut Triono (2017:80) adalah suatu prosesyang dilakukan serta dipergunakan oleh pembaca untuk memperolehpesan yang hendak disampaikan oleh penulis melalui media kata- kata/bahasa tulis.Kemampuan membaca anak harus diasah sejak dini melalui kegitan membaca permulaan. Membaca permulaan merupakan kegiatan membaca yang di lakukan oleh siswa melalui tahapan dengan memperkenalkan huruf atau abjadserta sekaligus membelajarkan cara penyebutan huruf atau intonasi yang jelas dan benar.Kemampuan membaca yang masih rendah membutuhkan suatu rangkain pembelajaran yang menarik. Proses belajar mengajar yang dilakukan oleh guru dan siswa didalam kelas menentukan keberhasilan belajar siswa. Maka seorang guru harus menyusun kegiatan pembelajaran dengan menerapkan berbagai metode pembelajaran untuk menarik perhatian dan semangat belajarsiswa.

Metode pembelajaran dalam proses kegiatan belajar mengajar sangat dibutuhkah untuk menunjang kemampuan membaca siswa. Metode merupakan suatu cara penyampaian materi untuk mencapai tujuan pembelajaran yang telah ditetapkan. Seorang guru harus mampu memilih metode yang baik agar siswatidakbosan. Khususnya kelas rendah yang lebih aktif dan suka bermain.

Metode yang sering digunakan untuk meningkatkan kemampuan membaca siswa yaitu metode eja. Metode eja merupakan metode yang digunakan untuk memperkenalkan huruf-huruf kepada siswa yaitu mengeja huruf demi huruf. Siswa diperkenalkan dengan lambang- lambang huruf, kemudian dari huruf tersebut dirangkai menjadi suku kata. Metode eja ini di perkenalkan dari abjad atau huruf A sampai dengan huruf $Z$. Penerapan metode pembelajaran yang tidak bervariasi akan menyebabkan kurangnya semangat dan minat membaca siswa.
Berdasarkan hasil observasi dan wawancara yang telah dilakukan di SDN 024 Tarakan kelas II memperoleh beberapa permasalahan yaitu terdapat beberapa siswa yang kurang dalam membaca, di antaranya kurang dalam membedakan huruf serta ada beberapa siswa yang belum mengetahui hubungan antara bunyi dan bentuk huruf. Permasalahan lainnya yaitu kurangnya variasi mengajar guru dalam penggunaan metode dan model pemebalajaran sehingga siswa menjadi kurang semangat dalam membaca. Guru menuliskan bahan materi di papan tulis atau mendikte buku pembelajaran itu sendiri, dan guru kekurangan media dalam membantu siswa meningkatkan kemampuan membaca. Oleh karena itu dibutuhkannya penggunaan metode yang dapat meningkatkan kemampuan membacasiswa.

Salah satu metode pembelajaran yang dapat di gunakan untuk meningkatkan kemapuan membaca anak adalah metode Suku Kata. Metode Suku Kata adalah metode yang digunakan oleh guru dengan memperkenalkan suku kata yang sudah dirangkai kata-kata terlebih dahulu, kemudian dari suku kata tersebut di rangkai menjadi kata dan kata di rangkai menjadikalimat.

Keberhasilan suatu proses pembelajaran dapat dikatakan berhasil apabila siswa dapat mengerti dan memahami apa yang disampaikan oleh guru. Berdasarkan Metode Suku Kata ini dapat membatu siswa dalam meningkatkan kemampuan membaca. Proses penerapan metode suku kata yang lebih efektif untuk membantu siswa dalam meningkatkan kemampuan membaca dapat disandingkan dengan media pembelajaran, media pembelajaran yang digunakan yaitu media kartu kata. Media kartu kata merupakan media pembelajaran yang di gunakan untuk memudahkan siswa dalam meningkatkan kemampuan membaca. Media kartu kata ini dibentuk dan di sesuaikan oleh guru berdasarkan materi dan metode atau model pembelajaran yang akan di ajarkan dan di laksanakan didalamkelas.

Berdasarkan latar belakang di atas, maka peneliti tertarik untuk melaksanakan penelitian dengan judul "Perbandingan Metode Suku Kata dan Metode Eja Berbantuan Media Kartu Kata Terhadap Kemampuan Membaca Permulaan 
Siswa Kelas II di SDN 024 Tarakan". variabel yang akan di teliti ialah variabel bebas dengan penerapan Metode Suku Kata Dan Metode Eja BErbantuan Media Kartu Kata, variabel terikat ialan Kemampuan MembacaPermulaan

\section{Metode}

Jenis penelitian yang digunakan dalam penelitian ini adalah kuantitatif jenis eksperimen. Sugiyono (2015:107) Metode penelitian eksperimen adalah sebagai metode penelitian yang digunakan untuk mencari pengaruh perlakuan tertentu dalam kondisi yang tak terkendalikan. Objek penelitian ini adalah perbandingan Metode Suku Kata dan Metode Eja berbantuan Media Kartu Kata terhadap kemampuan membaca permulaan siswa kelas II di SDN 024 Tarakan.

Desain penelitian ini adalah quasi experimental design dengan bentuk desain nonequeivalent control group design. Menurut Sugiyono (2015: 144) quasi experimental design adalah desain yang memiliki kelompok kontrol, tetapi tidak berfungsi sepenuhnya untuk mengkontrol variabel luar yang mempengaruhi pelaksanaan eksperimen. Dalam desain ini terdapat dua kelompok penelitian yaitu kelompok eksperimen dan kelompok kontrol. Desain penelitian ini akan diterapkan dua kali tes, yaitu sebelum (pretest) diberi perlakuan dan sesudah perlakuan (posttes) diberi perlakuan. Penelitian ini dilaksanakan di SDN 024 Tarakan pada kelas II Semster Ganjil TahunAjaran2019/2020 yang terletak di jalanMelati RT. 24 Kampung Bugis Kelurahan Karang Anyar Kecematan Tarakan Barat. Waktu pelaksanaan penelitian ini dilaksanakan pada tanggal 19-31 Agustus2019.

Populasi dalam penelitian ini adalah siswa kelas II yang ada di SDN 024 Tarakan tahun pelajaran 2019/2020 yang berjumlah 111 siswa dan dibagi kedalam 4 kelas. Adapun teknik pengambilan sampel dalampenelitian ini adalah teknik random sampling. Menurut Sugiyono (2017:82) simple random sampling merupakan pengambilan anggota sampel secara sederhanna dari populasi dilakukan secara acak tanpa memperhatikan strata yang ada dalam populasi. Sampel dalam penelitian ini adalah siswa kelas II D sebagai kelas eksperimen dan siswa kelas II C sebagai kelaskontrol.
Variabel adalah segala sesuatu yang berbentuk apa saja yang akan ditetapkan oleh peneliti untuk dipelajari sehingga diperoleh informasi tentang hal tersebut, kemudian ditarik kesimpulan. Menurut Arikunto(2013:161) Variabel adalah objek penelitian, atau apa yang menjadi titik perhatian suatu penelitian. Dalam statistik dikenal dua jenis variabel yang dikaji dengan dua jenis variabel, yaitu variabel yang mempengaruhi (bebas/independen) dan variabel akibat (terikat/dependen). Variabel bebas dalam penelitian ini adalah penerapan Metode Suku Kata dan Metode Eja Berbantuan Media Kartu Kata. Sedangkan variabel terikat dalam penelitian ini adalah kemampuan membaca permulaansiswa.

Teknik pengumpulan data dalam penelitian ini berupa observasi, wawancara dan menggunakan penilaian kinerja (Performance Assesment) yaitu instrumen penilaian kemampuan membaca permulaan. Instrumen penilaian kemampuan membaca permulaan berupa tes (pretest dan posttest). Sebelum melakukan penelitian diperlukan pengujian instrumen dengan melakukan uji validitas. Uji validitas yang dilakukan adalah uji validitasi internal, yang terdiri dari validitas konstruksi (construk validity) dan validitas isi (content validity). Validasi yang digunakan dalam penelitian ini untuk menilai valid tidaknya teks suku kata pada instrumen penilaian kinerja (performance assesment) untuk mengukur kemampuan membaca permulaansiswa.

Validasi instrumen ini dilakukan dengan memberi tanda centang $(\sqrt{ })$ pada kolom (YA) untuk suku kata yang sesuai dan memberi tanda (X) pada kolom (TIDAK) untuk suku kata yang tidak sesuai, kemudian akan akan dituliskan suku kata yang sesuai pada kolom saran. Hasil dari validasi instrumen penilaian kinerja (performance assesment) untuk mengukur kemampuan membaca permulaan siswa, yaitu instrumenlayak dipergunakan tanparevisi.

Teknik analisis data dalam penelitian ini menggunakan analisis inferensial.Analisisi inferensialterbagi menjadi dua uaitu uji asumsi prasyarat yang terdiri dari uji normalitas dan uji homogenitas. Setelah terpenuhi uji asumsi prasyarat maka bisa dilakukan uji hipotesis. Pengujian hipotesis bertujuan mengetahui ada tidaknya perbedaan kemampuan membaca 
permulaan dengan menggunakan Metode Suku Kata dan Metode Eja Berbantuan Media Kartu Kata Siswa Kelas II di SDN 024 Tarakan.

\section{Hasil Dan Pembahasan}

Penelitian ini dilaksanakan pada siswa kelas II SDN 024 Tarakan semester ganjil tahun ajaran 2019/2020 pada mateti Tema 2 Bermain dilingkunganku Sub tema 1 Berman di lingkungan rumah. Penelitian ini menggunakan dua kelas yaitu kelas II D berjumlah 28 siswa sebagai kelas eksperimen dengan menerapkan Metode Suku Kata Berbantuan Media Kartu Kata dan kelas II C berjumlah 27 siswa sebagai kelas kontrol dengan menerapkan Metode Eja Berbantuan Media Kartu Kata. Penelitian ini dilakukan sebanyak 6 kali pertemuan (1 sub tema dengan 6pembelajaran)alokasi waktu $6 \mathrm{x}$ 30 menit.

Data penelitian diperoleh dari hasil kemampuan membaca permulaansiswa (pretest dan posstest)setelahadanya pembelajaran pada kelas eksperimen dan kelas kontrol. Data hasil kemampuan membaca permulaan diukur dengan penilaian kinerja (Performance Assesment) yaitu instrumen kemampuan membaca permulaan. Pengolahan data kuantitatif pada penelitian ini menggunakan software 21.0 for windows.

Data hasil pretest yang dilakukan didapatkan nilai rata-rata kelas, pada siswa eksperimen rata-rata nilai siswa adalah 60,93 sedangkan pada elas kontrol adalah 60,78 . Hasil posttest juga diperoleh nilai rata-rata siswa. Nilai rata-rata siswa pada kelas eksperimen adalah 84,75 dan nilai rata-rata pada kelas kontrol adalah 84,52. Dari rata-rata posttest pada kelas eksperimen dan kelas kontrol tersebut dapat dikatakan bahwa kedua kelas mengalami peningkatan kemampuan membaca permulaan setelah diterapkan Metode Suku Kata berbantuan media kartukata.

1. Uji Asumsi Prasyarat

a. Uji Normalitas

Uji normalitas dilakukan untuk mengetajui apakah sampel yang diteliti berasal dari populasi yang berdistribusi nomal atau tidak. Untuk menguji normalitas data dapat digunakan uji statistik kolmogorov-smirnov dengan taraf signifikan 5\% $(\alpha=0,05)$. Berdasarkan perhitungan software SPSS versi
21.0 for windows, hasil data dapat dilihat padaTabel 1berikut:

Tabel 1. Uji Normalitas Kelas Eksperimen dan Kelas Kontrol

\begin{tabular}{lllll}
\hline Kelas & Penilaian & $\begin{array}{l}\text { Sig } \\
\text { (p) }\end{array}$ & $\begin{array}{l}\text { Kondi } \\
\text { si }\end{array}$ & Ket \\
\hline Eksp & Pretest & 0,582 & $\mathrm{P} \geq 0,05$ & Normal \\
& Posttest & 0,933 & $\mathrm{P} \geq 0,05$ & Normal \\
Kontrol & Pretest & 0,229 & $\mathrm{P} \geq 0,05$ & Normal \\
& Posttest & 0,669 & $\mathrm{P} \geq 0,05$ & Normal \\
\hline
\end{tabular}

Berdasarkan Tabel 1 diperolah nial signifikan data pretest dan posttest pada kelas eksperimen dan kelas kontrol diatas taraf signifikan $(\alpha=0,05)$, sehingga dapat disimpulkan data hasil uji normalitas pada kelas eksperimen dan kelas kontrol berdistribusinormal.

b. Uji Homogenitas

Uji homgenitas menggunakan bantuan software SPSS versi 21.0 for windows dengan uji Levene's test smirnov. Kriteria pengambilan keputusan dan penarikan kesimpulan terhadap uji homogenitas dilakukan pada taraf signifikan 5\% $(\alpha=0,05)$. Apabila signifikansinya lebih dari 0,05 maka dapat disimpulkan bahwavariannya sama (homogen), namun apabila variannya kurang dari 0,05 maka variannya berbeda (tidak homogen). Hasil data homogenitas dapat dilihat pada Tabel 2 berikut.

Tabel 2. Uji Homogenitas Kemampuan Membaca Permulaan

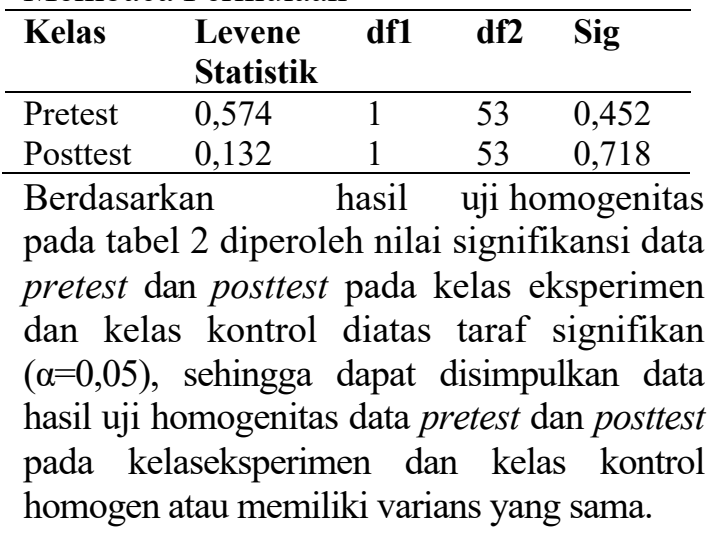

2. Uji Hipotesis

Berdasarkan hasil uji asumsi prasyratan berupa uji normalitas dan uji homogenitas, 
maka diperoleh kesimpulan bawah kelas eksperimen dan kelas kontrol berdistribusi normal dan homogen. Setelah uji asumsi prasyarat terpenuhi, maka selanjutnya adalah menguji hipotesis. Berdasarkan perbedaan nilai pretest- posttest kelas eksperimen dan kelas kontrol akan dilakukan uji statistik Independent Sample t-Test. Uji hipotesis statistik dilakukan terhadap perbedaan kemampuan membaca permulaan siswa. Uji ini digunakan dengan mengambil keputusan apakah hipotesis diterima atauditolak.

Hasil analisis uji hipotesis data yang telah dilakukan oleh peneliti dengan menggunakan Independent Sample t-Test diperoleh $t_{\text {hitung }}=0,045$. Pada taraf signifikasi 0,05 dan $\mathrm{df}=53$, diperoleh $\mathrm{t}_{\text {tabel }}=$ 2,01 , maka diperoleh thitung $\leq$ tabel $(0,045$ $\leq 2,01)$. Dengan thitung $\leq$ tabel maka hipotesis nol (Ho) diterima dan hipotesis alternatif (Ha) ditolak.

Dari hasil uji hipotesis ini maka dapat disimpulkan bahwa tidak terdapat perbedaan kemampuan membaca permulaan dengan menerapkan Metode Suku Kata dan Metode Eja Berbantuan Media Kartu Kata Siswa Kelas II di SDN 024 Tarakan. Hal ini dikarenakan Kelas eskperimen menerapkan Metode Suku Kata Berbantuan Media Kartu Kata. Metode Suku Kata adalahmetodeyang dapat diterapkan untuk melatih kemampuan membaca permulan siswa, karena penerapan metode ini dimulai dengan menyediakan kata terlebih dahulu, kemudian dari kata tersebut dikupas menjadi suku kata dan dari kata dirangkai menjadi kata dan selanjutnya belajar menyambungkan kata menjadi suatu kalimat sederhana. Berdasarkan hal ini, sejalan dengan Mustikawati (2015:46) menyatakan bahwa metode suku kata adalah penerapan pengenalan huruf kepada siswa yaitu dengan merangkaikan suku kata menjadi huruf dan akhirnya menjadi kata. Berdasarkan penelitian yang telah dilakukan oleh peneliti, adapun kelebihan metode suku kata yaitu siswa lebih memahami huruf berdasarkan bunyi serta mengenal suku kata dari suatu kata. Hal ini sejalan dengan Muslihah (2015:23) menyatakan bahwa kelebihan dari metode suku kata diantaranya yaitu: dapat belajar mengenal huruf dengan mengupas atau menguraikan suku kata yang dipergunakan dalam unsurunsurhurufnya.

Sedangkan Kelas kontol merupakan kelas yang menerapkan Metode Eja berbantuan Media Kartu Kata. Metode Eja merupakan metode dengan proses pengenalan huruf- huruf kepada siswa serta pengenalan bunyi pada huruf kemudian mengenalkan lambang bunyi huruf dan melafalkan bunyi pada setiap huruf. Berdasarkan pengertian metode eja menurut Mulyono (2012:172) yaitu suatu metode pembelajaran yang menekankanpadapengenalan kata melalui proses pendengaran bunyi huruf. Kelebihan dari metode eja yaitu siswa mudah memahami setiap huruf berdasarkan bunyi dan lambang huruf, kemudian siswa lebih tanggap mengetahui suatu susunan suku kata menjadi kata yangtepat.

Penerapan metode suku kata pada kelas eksperimen dan metode eja pada kelas kontrol dengan kedua kelas tersebut berbantuan media kartu kata. Sehingga menambah pemahaman siswa dalam kegiatan membaca. Media kartu kata merupakan media pembelajaran yang digunakan untuk membantu siswa lebih memahami huruf, suku kata, kata dan menjadi suatu kalimat sederhana. Media suku kata dibuat dan dibentuk sedemikian rupa untuk menarik minat dan perhatian siswa dalam kegiatan membaca. Hala ini terbukti yang telah dilakukan oleh peneliti yaitu siswa lebih aktif dan termotivasi dalam kegiatan membaca, sehingga siswa tidak merasa bosan, bahkan siswa bermain sambil belajar dengan media tersebut. Sejalan dengan Yushalihin (2017:13) mengatakan bahwa media kartu kata adalah media yang berisi suatu katayang memiliki arti yang berisikan dengan tulisan huruf-huruf abjad yang tersusun membentuk kata yang mempunyaimakna.

\section{Kesimpulan}

Hasil penelitian tentang perbandingan Metode Suku Kata dan Merode Eja Berbantuan Media Kartu Kata Terhadap Kemampuan Membaca Permulaan Siswa Kelas II di SDN 024 Tarakan pada semester ganjil tahun pembelajran 2019/2020 maka diperoleh kesimpulan sebagai berikut: Tidak terdapat perbedaan kemampuan membaca permulaan dengan menerapkan 
Metode Suku Kata dan Metode Eja berbantuan Media Kartu Kata Terhadap Kemampuan Membaca Permulaan Siswa Kelas II di SDN 024 Tarakan. Hal ini dapat dilihat dari hasil uji Independent Sample T-test terhadap kelas eksperimen yang menerapkan Metode Suku Kata dan kelas kontrol yang menerapkan Metode Eja dengan berbantuan media kartu kata ditinjau dari kemampuan membaca permulaan siswa diperoleh $t_{\text {hitung }}=0,045$. Pada taraf signifikasi 0,05 dan $\mathrm{df}=53$, diperoleh $\mathrm{t}_{\text {tabel }}=$ 2,01 , maka dapat disimpulkan $t_{\text {hitung }} \leq t_{\text {tabel }}(0,045$ $\leq 2,01)$. Sehingga dapat disimpulkan $t_{\text {hitung }} \leq \mathrm{t}_{\text {tabel }}$ dengan ketentuan Ho diterima dan Haditolak.

Berdasarkan kesimpulan diatas adapun saran dalam penelitian ini adalah sebagai berikut: Kegiatan membaca bagi siswa sangat penting, membaca di kelas rendah merupakan kegiatan membaca permulaan untuk kegiatan membaca lanjut di kelas tinggi. Pada saat ini, penyediaan informasi sebagian besar tersediadalam bentuk teks. Maka dari itu, guru yang ada di Sekolah Dasar terutama untuk guru kelas rendah harus menggunakan suatu variasi dalampenerapan metode atau model pembelajaran untuk meningkatkan kemampuan membaca siswa. Metode dan model pembelajaran sangat banyak dan beragam, guru harus melihat kondisi dan keadaan siswa dalam penggunaan metode atau model pembelajaran.

Beberapa metode yang dapat digunakan untuk meningkatkan kemampuan membaca siswa yaitu: Metode Eja, Metode Suku kata, Metode kata, Metode Bunyi, Metode Global dan Metode SAS. Keenam metode tersebut merupakan metode yang dapat digunakan dalam meningkatkan kemampuan membaca siswa. Terutama metode suku kata dan metodeeja.

Metode Suku Kata dan Metode Eja dapat digunakan untuk meningkatkan kemampuan membaca permulaan, serta penggunaan media pembejaran yang sesuai yaitu media kartu kata yang dapat dibuat dan dibentuk oleh guru sesuai kreativitas untuk memotivasi siswa dalam membaca serta membuat siswa merasa tidak bosan. Siswa dapat bermain sambil belajar dengan media kartu kata tersebut. Sehingga metode suku kata dan metode eja berbantuan media kartu kata dapat di rekomendasikan untuk pembelajaran tematik di kelas awal.

\section{Daftar Pustaka}

Arikunto, Suharsimi. 2013. Dasar- dasar Evaluasi Pendidikan. Jakarta: PT. Bumi Aksara.

Mulyono, Abdurrahim. 2012. Anak Berkesulitan Belajar. Jakarta: PT RinekaCipta.

Muslihah, Ani. 2015. Penerapan Metode Suku Kata Untuk Meningkatkan Hasil Belajar Bahasa Indonesia Pokok Bahasan Membaca Siswa KelasI Mi Nurul Huda Klangon, Kec Ampel, Kab Boyolali Tahun Pelajaran 2015/2016. (Skripsi Online). Fakultas Tarbiyah Dan Ilmu Keguruan. Institut Agama Islam Negeri Salatiga. http://e- repository.perpus.iainsalatiga.ac. id/. (Diakses tanggal 10 Mei 2019)

Mustikawati, Ratih. 2015. Upaya Peningkatan Keterampilan Membaca Permulaan Dengan Metode Suku Kata (Syllabic Method) Pada Siswa Kelas I SD Negeri Nayu Barat III Banjarsari Surakarta Tahun 2014/2015. Jurnal Ilmiah Mitra Swaga Genesha 2(1) (Online). https:// Fejournal.utp.ac.id/.(11Mei 2019)

Pemerintah Republik Indonesia. 2003. "Undangundang Republik Indonesia Nomor 20 Tahun 2003Tentang Sistem Pendidikan Nasional"

Sugiyono. 2015. Metode Penelitian Pendidikan. Bandung: Alfabeta

Sugiyono. 2017. Metode Penelitian Kuantitatif, Kualitatif, dan $R \& D$. Bandung: Alfabeta

Suragangga, I Made Ngurah. 2017. Mendidik Lewat Literasi Untuk Pendidikan Berkualiatas. Jurnal Penjaminan Mutu. Denpasar. Jurnal Penjaminan Mutu 3 (3). http://ejournal.ihdn.ac.id. (Diakses tanggal 09 Mei2019)

Triono, Agus. 2017. Pembahasan Tuntas Kompetensi Bahasa Indonesia. Jakarta: Erlangga

Yusuf, Suhendra. Hayat, Bahrul. 2010. Mutu Pendidikan. Jakarta: Bumi Aksara 